Acta Poloniae Historica

122, 2020

PL ISSN 0001-6829

Rafat Rutkowski

https://orcid.org/0000-0002-1875-982X

Institute of Archaeology and Ethnology, Polish Academy of Sciences

\title{
WHY WOULD THE SKALDS NOT HAVE LIED ABOUT THE RULERS' EXPEDITIONS AND BATTLES? SOME REMARKS ON A RELIC OF MEDIEVAL ATTITUDE TOWARD SOURCES IN MODERN MEDIEVAL STUDIES*
}

\begin{abstract}
The article presents a critique of a research method whereby historical sources could not have possibly lied as they were targeted at the addressees who knew the actual course of the events described or referred to. This attitude toward the sources has its antecedence in Snorri Sturluson's argument on the reliability of skaldic poetry. To his mind, the poems were biased but still valuable, in a way, as they were declaimed before the rulers who would have perceived an untrue account "as a mockery, rather than a praise". The question arises, what kind of a situation Snorri tried to preclude: one where a mean warrior would have been shown as a great hero? Or, perhaps, one where a defector would have been portrayed as a warrior bravely marching in the first rank? The story of Giffard from the Morkinskinna saga seems to offer the answer. Giffard fled from the battlefield but had a praise poem dedicated to him, which the (real) character aptly deciphered as derision aimed at him.
\end{abstract}

Keywords: Snorri Sturluson, Morkinskinna, skaldic poetry, methodology of history, medieval historiography

* This article is incidental to the research that produced the book: Rafał Rutkowski, Pótnocna tradycja historyczna wprowadzona w nurt dziejów powszechnych. Kronika Mnicha Teodoryka "O starożytności norweskich królów” (koniec XII wieku) (Toruń, 2019), esp. 214-33. It was first delivered at the conference "Warrior traditions in mediaeval historical culture", held at the Institute of History, Polish Academy of Sciences, in December 2016. I am indebted to all those who have shared their remarks or comments regarding the text. 
Louer les princes des vertus qu'ils n'ont pas, c'est leur dire impunément des injures. ${ }^{1}$

Snorri Sturluson, the Icelandic sagamadr and statesman living in the late twelfth and early thirteenth century, was not the only medieval author to have quoted skaldic poetry in his works; ${ }^{2}$ however, he was virtually the only one to have assumed - namely, in the prologues to Heimskringla and the Separate Saga of St Olaf ${ }^{3}$ - a comprehensive attitude toward these verses' usability as historical sources. It can be outright said that he commenced a discussion on the origins and reliability of this poetry, which has been ongoing until now, with scholarly methods employed these days. ${ }^{4}$ Some of the arguments formulated by Snorri have obviously been undermined - primarily, the view that the versification of the poems and, consequently, their factual content, remained resistant to changes. This is challenged by the differences in the various records containing the same pieces. ${ }^{5}$

${ }^{1}$ Réflexions, sentences et maximes morales de La Rochefoucauld, ed. by Charles-Augustin Sainte-Beuve (Paris, 1867), 58; cf. Sigurður Nordal, Snorri Sturluson (Reykjavík, 1973), 166.

${ }^{2}$ Of the recent literature on Snorri and his works, worthy of note are: Sverre Bagge, Society and Politics in Snorri Sturluson's "Heimskringla" (Berkeley, 1991); Diana Whaley, "Heimskringla". An Introduction (London, 1991); Elisabeth Ashman Rowe, 'Historical Invasions/Historiographical Interventions: Snorri Sturluson and the Battle of Stamford Bridge', Medievalia, xvii (1994), 149-76; Anthony Faulkes, 'The Sources of Skáldskaparmál: Snorri's Intellectual Background', http://www. vsnrweb-publications.org.uk/Sources-of-Skaldskaparmal.pdf [Accessed: 29 March 2020]; id., 'Descent from the Gods', http://www.vsnrweb-publications.org.uk/ Descent-from-the-gods.pdf, [Accessed: 29 March 2020]; Patricia P. Boulhosa, Icelanders and the Kings of Norway. Medieval Sagas and Legal Texts (Leiden-Boston, 2005), 6-21; Kevin J. Wanner, Snorri Sturluson and the Edda. The Conversion of Cultural Capital in Medieval Scandinavia (Toronto, 2008).

${ }^{3}$ On both these accounts, see Sverrir Tómasson, Formálar íslenskra sagnaritara á miðöldum. Rannsóknbók menntahefðar (Reykjavík, 1988), 374-83.

${ }^{4}$ This point is also raised, although with some reservations, in Preben Meulengracht Sørensen, 'The Prosimetrum Form. 1: Verses as the Voice of the Past', in Skaldsagas: Text, Vocation, and Desire in the Icelandic Sagas of Poets, ed. by Russell Poole (Berlin-New York, 2000), 175.

${ }^{5}$ For a comparative discussion on the formulaic character of oral accounts, see Walter J. Ong, Orality and Literacy: The Technologizing of the Word (London-New York, 2002²). 
Despite differences appearing in detailed findings and the methodology used, the impression remains that it was Snorri who set the threads for the discussion that has continued to date, never so far resolved (if resolvable at all). ${ }^{6}$ The following remarks deliberately form part of this convention, from a somewhat broader perspective.

Comprehensive studies on Snorri's historiographic technique have a long tradition behind them; hence, there is no need to refer herein to all the related problems. Among the numerous arguments put forth by Snorri in favour of credibility of the skaldic poetry, I shall pick up the one concerning the audiences which were formed of eyewitnesses and controlled the reliability of the poets. As Snorri puts it,

we have mostly used as evidence what is said in those poems that were recited before the rulers themselves or their sons. We regard as true everything that is found in those poems about their expeditions and battles. It is indeed the habit of poets to praise most highly the one in whose presence they are at the time, but no one would dare to tell him to his face about deeds of his which all who listened, as well as the man himself, knew were falsehoods and fictions. That would be a mockery and not praise. ${ }^{7}$

This somehow short eduction interests me for several reasons. Above all, its reasoning - which basically says that records could not lie as the listeners would have rejected them - still functions in our contemporary medieval studies, as a peculiar relic. Sverre Bagge had

${ }^{6}$ Let me refer the reader to the following studies: Roberta Frank, 'Skaldic Poetry', in Carol J. Clover and John Lindow (eds), Old Norse-Icelandic Literature. A Critical Guide (New York, 1985), 157-96; Carl Phelpstead, Holy Vikings: Saints' Lives in the Old Icelandic Kings' Sagas (Tempe, 2007), 120 ff.; Theodore M. Andersson, 'The Oral Sources of Óláfs Saga helga in Heimskringla', Saga-Book, xxxii (2008), 5-38; Shami Ghosh, Kings' Sagas and Norwegian History. Problems and Perspectives (Leiden-Boston, 2011), 25-109; Jakub Morawiec, Między poezja a polityka. Rozgrywki polityczne w Skandynawii XI wieku w świetle poezji ówczesnych skaldów (Katowice, 2016).

${ }^{7}$ Snorri Sturluson, Heimskringla. Nóregs Konunga Sögur, ed. by Finnur Jónsson, i-iii (København, 1893-1901), i, 'Prologue', 6: "ok tókum vér par mest dœmi af pvi, er sagt er í peim kvæðum, er kveðin váru fyrir sjálfum höfðingjunum eða sonum peira; tökum vér pat alt fyrir satt, er í peim kvæðum finnsk um ferðir peira eða orrostur; en pat er háttr skálda, at lofa pann mest, er pá eru peir fyrir, en engi myndi pat pora, at segja sjálfum honum pau verk hans, er allir peir, er heyrði, vissi, at hégómi væri ok skrök, ok svá sjálfr hann; pat væri pá háð, en eigi lof"; Snorri Sturluson, Heimskringla, transl. Alison Finlay and Anthony Faulkes, i: The Beginnings to Óláfr Tryggvason (London, 2011), $3 \mathrm{f}$. 
expressed his overt approval of this fact; this outstanding Norwegian medievalist perceives Snorri's criticism and his strive for controlling source-based information as "essential to all [emphasis mine - R.R.] historical research"8 (this large quantifier points to a generalising character of the statement). Bagge is right in that Snorri's assumption is continually used as an argument in favour of the source's reliability. The question appears, though, whether it is critical thinking indeed, and whether Snorri should really be identified as a godfather of modern historiography? ${ }^{9}$ Otherwise, the reverse would be true: remnants of medieval thinking about the past still function in the historiography of today.

It will probably be no abuse on my part to use, in this text on Old Icelandic sagas, some quotes from medievalists dealing with continental issues, limiting myself to a few examples - starting from the dating of the so-called Mathilde's Letter. As a scholar tells us, this record could not have been written before the political disaster that affected King Mieszko II in the year 1031: after all, it "praises the Polish monarch's greatness with considerable blatancy". This being the case, the medievalist rhetorically asks, "could it be presumed at all that somebody would have dared to write such a letter in the atmosphere of the years that followed the disaster? Would the author have not feared that Mieszko would consider it a mockery" ${ }^{10}$ Let me try and answer with the question: is it not an instance of mixing two different discourses? In other words, is the Mieszko from the letter identical with the figure known to us from the other sources - primarily, the scholarly literature? On the other hand, being a ruler, did he not deserve some compliments from the duchess in his latest years? The conviction that a panegyric form is due to reflect the reality is delusive, for it belongs to another ontological order - describing the expected, rather

${ }^{8}$ Sverre Bagge, review of Kings' Sagas and Norwegian History. Problems and Perspectives by Shami Ghosh, Journal of English and Germanic Philology, cxii, 1 (2013), 98-103 (here: 99).

${ }^{9}$ In quite a similar manner, William of Newburgh, who repeatedly reports on so-called revenants, has been deemed to be a precursor of modern historiography, Nancy F. Partner, Serious Entertainments. The Writing of History in Twelfth-Century England (Chicago-London, 1977), 65-8; cf. Antoni Grabowski, 'Wilhelma z Newburgh "Noc Żywych Trupów"', Przeglad Historyczny, cx, 1 (2019), 1-18.

${ }_{10}$ Roman Michałowski, Princeps fundator. Studium $z$ dziejów kultury politycznej w Polsce X-XIII wieku (Warszawa, 1993²), 54. 
than the factual, state-of-affairs. ${ }^{11}$ And, I should think, such a form is welcome in any situation. Even the annalist of Hildesheim, who was disinclined to Mieszko, praised him after his death for his dissemination of the Christian religion. ${ }^{12}$ Was this praise improper as well?

Similar reasoning can be found in the research on the Gallus Anonymus chronicle: the 'things (allegedly) unsaid' in the statements on the nameless bishop (the one identified with St Stanislaus), or on Zbigniew, were explained by the political expectations of the chronicler's patrons who were believed to have well remembered the course of the events. ${ }^{13}$ At last, we arrive at the 'ritual' medievalstudies school, willingly endorsing the 'reliability' of every message or record concerning rituals; ${ }^{14}$ again, the 'reader control' argument has usually been used in such contexts. However, as Philippe Buc has noticed, this approach "underestimates the freedom enjoyed by early medieval authors; their audience's knowledge of facts did not constrain their ability to weave fictions beyond mere amplifications and elisions. Rulers and other aristocrats fully expected fictions to be woven by authors of books (and, we must assume, of texts to be declaimed

${ }^{11}$ Cf. id., 'Relacja Galla Anonima o zjeździe gnieźnieńskim - problem wiarygodności', in Barbara Trelińska (ed.), Tekst źródta - krytyka i interpretacja (Warszawa, 2005), $58 \mathrm{f}$. This author remarks that Gallus's narrative on the rule of Boleslaus the Brave (Bolesław Chrobry) is overly monumentalised (from our standpoint) but still allows to draw reliable information on the period's realities. This stance is criticised by Jacek Banaszkiewicz, 'Gall jako historyk poważny, czyli dlaczego dzieje i Bolesława Chrobrego, i Bolesława Krzywoustego są prawdziwe i niegroteskowe', in id., Takie sobie średniowieczne bajeczki (Kraków, 2012), 563-85; the rules governing the represented world are emphasised there. The opinion of another medievalist, who believes that "It is this bias [i.e. as pointed by Michałowski in respect of Gallus] that seems particularly interesting to us", is apt on the declarative level only, Marian Dygo, 'Uczty Bolesława Chrobrego', Kwartalnik Historyczny, cxii, 3 (2005), 46.

${ }^{12}$ Annales Hildesheimenses, ed. by Georg Waitz, Monumenta Germaniae Historica, Scriptores rerum Germanicarum in usum scholarum separatim editi (Hannoverae, 1878), s.a. 1034, 38; cf. Andrzej Pleszczyński, The Birth of a Stereotype. Polish Rulers and their Country in German Writings c. 1000 A.D., transl. Robert Bubczyk (Leiden-Boston, 2011), $293 \mathrm{f}$.

${ }^{13}$ For a critique of such views, see Anna Gronowska, 'Fabuły rycerskie w "Gesta ducum sive principum Polonorum" Galla Anonima na tle wybranych przykładów piśmiennictwa średniowiecznego (do końca XIII w.)', an unpublished PhD thesis, University of Warsaw (Warszawa, 2009), 131-4.

${ }^{14}$ This is how it is described in Jacek Banaszkiewicz, 'Łóżko i czapka. Kilka uwag o współczesnej rytualizacji średniowiecza', in id., W stronę rytuałów $i$ Galla Anonima (Kraków, 2018), 182-209. 
orally)". ${ }^{15}$ Following Buc's remark, the assumption that the truthfulness of medieval authors was subjected to the control of the readers, is risky, for a series of reasons. True, it tends to be taken for granted and on an a priori basis, the (nonexistent) audiences being merely an unverifiable mirage. First of all, however, there is the underlying conviction that the real course of events was known not only to the authors of the records concerned but also by their readers; moreover, they were able to reconstruct and critically evaluate it, much in the way modern historians would do. ${ }^{16}$ In fact, the beginnings of critical and rational thinking about the past are traceable, at most, to the late Middle Ages ${ }^{17}$ (certain forms characteristic of the previous epochs lasted in it for a long time). Much in brief, the earlier historiography was supposed to have stored the ideas of importance to the given community and show things as they 'should have been' rather than as they really were; its reception was founded not on métier rules but on the authority, perceived in moral terms, and the power of literary expression. ${ }^{18}$

The fact that such a catchall is of limited use and is only operable for a relatively narrow temporal horizon, delimited by the human memory, is fairly negligible. The consequences of such an assumption may lead down a methodologically blind alley: it namely allows to rescue the reliability of the information that cannot possibly be confirmed in any other way whatsoever - be it with use of another, independent source. Reducing the thing ad absurdum, almost everything that was written in the Middle Ages about a near past would have immediately become reliable due only to the fact that it assumed the form of a written text that was read by somebody. Every historian, I should suppose, would agree that the records contain pieces of information which are anything but credible, and yet they were written down for some reason (be it out

15 Philippe Buc, 'Noch einmal 918-919. On the Ritualized Demise of Kings and of Political Rituals in General', in Gerd Althoff (ed.), Zeichen, Rituale, Werte: Internationales Kolloquium des Sonderforschungsvereichs 496 an der Westfälischen WilhelmsUniversität Münster (Münster, 2004), 169. For a discussion on the debate to which Buc contributed his article, see Antoni Grabowski, 'Ostatnie studia o Liudprandzie z Cremony', Studia Źródtoznawcze, li (2013), 100 f.; id., The Construction of Ottonian Kingship. Narratives and Myth in Tenth-Century Germany (Amsterdam, 2018), 47-83.

${ }^{16}$ Cf. Paweł Żmudzki, 'New Versions of the Tales of Gallus Anonymous in the Chronicle of Master Vincentius', Acta Poloniae Historica, cxiii (2015), 143.

${ }^{17}$ See Krzysztof Pomian, Przesztoś́ jako przedmiot wiedzy (Warszawa, 2010).

${ }^{18}$ See Krzysztof Pomian, Przeszłość jako przedmiot wiary. Historia i filozofia w myśli średniowiecza (Warszawa, 2009²); Gronowska, Fabuty rycerskie, $11 \mathrm{ff}$. 
of ignorance or in order to mislead somebody). What can be said of the quite frequent situations of discrepancies occurring between records related to the same events? The assumption that every such source (why not every single one?) had to take into account the witnesses' opinion would have only intensified the Rashomon effect. ${ }^{19}$ Moreover, it is hard to expect that anybody would have been consistent enough to have used such arguments concerning stories on dragons, sorcerers, or successful trials by fire, for that matter; this would be naïve on my part. The fundamental thing is, what namely a scholar is willing to consider reliable or credible. At this point, however, discretion creeps into the research method: where is the border between things that, in the historical records, correspond with our conviction about what is rational, and things that collide with such conviction? Stories of both sorts were told with the use of the same bag of literary tricks; the stories of Sigurd the Crusader (to stick to Scandinavian threads) are basically as 'fabulous' as those on the ancestors of Harald the Fairhair (and vice versa: both were identically 'historical' and 'genuine' from the standpoint of medieval authors). ${ }^{20}$

It has to be admitted that since Snorri's time historiography has made enormous progress both in terms of increase of knowledge and development of research methods. Thus, the reasoning that refers to the witness control aspect can be read as a relic of medieval historiography. In order to demonstrate it, I will break down Snorri's argument into prime factors. Let me start by observing that the Icelandic sagamadr refers to witnesses not as his direct source but, indirectly, as listeners of his sources. The eyewitness issue has enormous literature which has undermined their authority and proposed to approach their lies, errors and omissions, and the determinants behind these, as a particular research problem. ${ }^{21}$ As regards the output of skalds, it has been

19 See Andrzej Garbicz and Jacek Klinowski, Kino wehikut magiczny. Przewodnik osiagnięć filmu fabularnego. Podróż druga 1950-1959 (Kraków, 1987), 25-8; Karl G. Heider, 'The Rashomon Effect: When Ethnographers Disagree', American Anthropologist, xc, 1 (1988), 73-81; Marek Cetwiński, Historia $i$ polityka. Teoria i praktyka mediewistyki na przykładzie badań dziejów Ślaska (Kraków, 2008), 226-30.

${ }^{20}$ Cf. Jacek Banaszkiewicz, 'Podanie o Lestku I Złotniku. Mistrza Wincentego “Kronika polska” I 9, 11', Studia Źródłoznawcze, xxx (1987), 40.

${ }^{21}$ For the Middle Ages, see e.g. Bernard Guenée, Histoire et culture historique dans l'Occident médiéval (Paris, 1980), 77 ff.; Jeanette M.A. Beer, Narrative Conventions of Truth in the Middle Ages (Genève, 1981); Grzegorz Myśliwski, 'Pamiętnicy. Ludzie 
remarked, for instance, that the individual poems were attributed to poets who either had not participated in the battle concerned or had fallen in it. ${ }^{22}$ At this point, the issue seems even more offbeat: the source-related utterance comes not from the witnesses of the events but from somebody who targeted it at the witnesses. In other words, rather than the way the skalds acquired their information, Snorri points to the way the information was subsequently verified. This would have worked as a guarantee of truthfulness of these, otherwise biased, poems. ${ }^{23}$ The question then arises, what kind of a representation of the battle clash would have been - in Snorri's opinion - unacceptable to those who listened to the skalds' poetry? Is it, simply, about an exaggerated emphasis of somebody's heroism or, perhaps, attributing glorious and praiseworthy deeds to a coward? What would the discord between the real events and the story about them essentially consist in? Is it a matter of simple distinction between true and false, or perhaps, of something else? And, lastly, does Snorri not overestimate the eyewitnesses he refers to?

The sagamadr's reasoning goes along the following track: if the skalds declaimed their pieces before the chiefs themselves, whilst they were wont to overemphasise their accomplishments, they could not have given false information as this would have been mistakenly perceived by the audiences ('as a mockery'). What kind of falsity is at work here? Lately, an interpretation of the Icelandic historiographer's has been proposed by Shami Ghosh in his study on the recent research into kings' sagas. As this historian suggests, according to Snorri, the skalds could not have overly embellished their stories, presenting, for instance, an average and not outstanding warrior as an eminent

sędziwi jako źródła wiedzy o przeszłości na ziemiach polskich (do końca XVI w.)', in Roman Michałowski et al. (eds), Europa barbarica, Europa christiana. Studia medievalia Carolo Modzelewski dedicata (Warszawa, 2008), 199-212; Jacek Banaszkiewicz, 'Narrator w przebraniu, czyli Mistrz Wincenty o bitwie mozgawskiej', in Andrzej Dąbrówka and Witold Wojtowicz (eds), Onus Athlanteum. Studia nad Kronika biskupa Wincentego (Warszawa, 2009), 423-34; Piotr Węcowski, 'Początki Polski w świetle zeznań świadków w procesie polsko-krzyżackim w 1422-1423 roku', in Andrzej Pleszczyński et al. (eds), Historia Narrat. Studia mediewistyczne ofiarowane Profesorowi Jackowi Banaszkiewiczowi (Lublin, 2012), 241-9; Halina Manikowska, 'Przeszłość wywołana - zeznania przed sądem', in ead. (ed.), Przeszłość w kulturze średniowiecznej Polski, ii (Warszawa, 2018), 333-402.

${ }^{22}$ See e.g. Meulengracht Sørensen, $185 \mathrm{f}$.

${ }^{23} \mathrm{Ibid}$., $175 \mathrm{f}$. 
hero. ${ }^{24}$ However, what Snorri essentially states is that this is what the skalds were doing, not shunning biased exaggerations; what he namely says is that it was their custom "to praise most highly the one in whose presence they are at the time".

What is more, the sagamadr's suggestion is that the poetry's panegyric character was not only tolerated but outright expected by the public. ${ }^{25}$ Putting it otherwise, rather than being supposed to tell the truth sine ira et studio, the skalds would have been expected to, merely, sing the praise of their patrons. All the same, their works, Snorri persuades, can be used as historical sources, and taken by the handful. Notably, there is no selection of information: the author gives reasons for the source's complete reliability, instead of offering its critique.

What is the author of Heimskringla actually after, in terms of exclusion of a situation? Is it not some unavoidable partiality that he is waving aside? An episode from Morkinskinna, the earliest (slightly earlier than Heimskringla) Icelandic compendium of kings' sagas, may appear instructive. The Magnus Barefoot's Saga from this collection tells the following story: a certain Norman knight called Giffard entered the service with King Magnus and accompanied his monarch in his expedition to Sweden. However, before the battle of Fuxerna, Giffard defected, thus revealing himself as a coward; the fight over, he arrived at the king's camp where he met with reluctance from the other warriors. So, he decided to return to England. While onboard the vessel, he met an Icelander named Eldjarn, who was on his way back from Constantinople. During a storm on the Northern Sea, Eldjarn saw Giffard asleep and composed a poem deriding his laziness. Once they set their foot on land, the knight charged Eldjarn with defamation. To cleanse himself of the accusation, Eldjarn wrote another poem, now in praise of Giffard's alleged heroic demeanour when at Fuxerna (the place from which he fled, thus dishonouring himself). In the light of the latter poem, the fighting was apparently very tough, and Giffard was reported to have single-handedly chased after the enemy warriors taking flight and beaten them to death. ${ }^{26}$ Having listened to

${ }^{24}$ Ghosh, Kings' Sagas, 51 ff., incl. recent literature. For my concise discussion with this interpretation, see Rafał Rutkowski, review of: Shami Ghosh, Kings' Sagas and Norwegian History, Studia Źródtoznawcze, liii (2015), 214.

${ }^{25}$ Similarly in Bagge, review of Ghosh, $98 \mathrm{ff}$.

${ }^{26}$ The way the skald presented Giffard's battlefield achievements reminds one of the Battle of Grunwald as depicted by Bishop Andrzej Łaskarzyc in his oration 
the piece of verse, Giffard aptly interpreted its purport: namely, "he knew in his heart that this was mockery and not praise, given what the circumstances were, but on no account did he want to reveal to people how he had comported himself at Foxerni". ${ }^{27}$ The judge to whom Giffard referred his complaint decided that the poem discredited nobody and, consequently, no legal action ought to be taken against the poet.

I am not drilling deep down into the details of this reasonably profound morality story, related to the evidently sarcastic portrayal of Giffard or his honorary contest with Eldjarn. I am only interested in this yarn's convergence with the Heimskringla prologue: both records feature the same phrase "mockery, rather than praise" (hád, en eigi lof). However, albeit Snorri must have known, and used, Morkinskinna, no Giffard episode whatsoever appears in his own Magnus Barefoot saga. Neither does it exist in any of the contemporary other records describing King Magnus's Swedish campaign - such as Theodoricus Monachus' chronicle, Ágrip, or Fagrskinna. Finnur Jónsson and Bjarni Aðalbjarnarson consequently believed that this episode was missing in the original text of the saga, composed around 1220 and available to Snorri; it would have been added at a later time. ${ }^{28}$ Sigurður Nordal and Kari Ellen Gade believed, in turn, that the original text

delivered before Antipope John XXIII in the autumn of 1411 (more than a year after the Teutonic Order's defeat): the bishop of Wrocław namely stated, contrary to the facts, that King Ladislaus Jagiełło joined the front rank of the troops he commanded. Łaskarzyc delivered his oration in presence of those who took part in the battle; Istud est membrum secundum collacionis, in Sven Ekdahl, Grunwald 1410. Studia nad tradycja i źródłami, transl. Maciej Dorna (Kraków, 2010), 285; cf. Marek A. Janicki, 'Grunwald w tradycji polskiej od wieku XV do XVII', in Dariusz Nowacki (ed.), Na znak świętego zwycięstwa. W sześśsetna rocznicę bitwy pod Grunwaldem (Paris-Kraków, 2010), 100-4; Paweł Żmudzki, 'Jak opisać bitwę pod Grunwaldem? Bellum Prutenum Jana z Wiślicy na tle historiografii średniowiecznej', in Jan M. Piskorski (ed.), Wojna, pamięć, tożsamość. O bitwach $i$ mitach bitewnych (Warszawa, 2012), 124.

${ }^{27}$ Saga Magnús berfoetts, chap. 43, in Morkinskinna, ed. by F. Jónsson (København, 1932), 323-6: "hann [sc. Gifffarðr] veit pat með ser at honom er petta hap en eigi lof at pvi sem ufni voro til. en illdi vist eigi gera pat bert fijire monnom verso Hann hatpi fram gengit a Foxerni"; Morkinskinna. The Earliest Icelandic Chronicle of the Norwegian Kings (1030-1157), transl. Theodore M. Andersson and Kari E. Gade (Ithaca-London, 2000), 305.

${ }^{28}$ Finnur Jónsson, Den oldnorske og oldislandske litteraturs historie, ii (København, 1923), 622 ff.; Bjarni Aðalbjarnarson, Om de norske kongers sagaer (Oslo, 1937), 158 , fn. 1. 
of Morkinskinna did contain this short story, and it was from it that Snorri had borrowed the above-quoted phrase. ${ }^{29}$

The question about the genetic filiation seems a secondary issue against the fact that the mockery/praise words appear in each of these works in different contexts. In one of them, we deal with a prologue, whereas the other offers a regular story. The link between them is, apparently, the single words. Even if we agree with Nordal and Gade, we would have to admit that Snorri used the phrase with considerable freedom, to satisfy his individual creative designs. Irrespective of this, it seems that the Morkinskinna episode might serve as a guideline to the proper understanding of Sturluson's disquisition. Let us now take a closer comparative look at both texts, ignoring Shami Ghosh's suggestion that the situations presented in them are 'incomparable'. ${ }^{30}$ As it has just been demonstrated, their juxtaposition has a long tradition behind it; both of them belong to the same literary genre - namely, the kings' saga. I think that a mind experiment is worthwhile based on the assumption that the adventure that came upon Giffard shows the practical meaning of Snorri's categories of 'mockery' and 'praise'.

So, Giffard was a coward who fled from the battlefield. Although he did not take part in the battle at all, his allegedly heroic conduct became the subject of Eldjarn's poem of praise. Instead of presenting the actual course of events, the poem was meant to ridicule the deserter, showing him as a hero standing courageously in the first rank. It was, de facto, not praise but a mockery. Snorri's argument is the following: the skalds exaggerated the achievements and deeds of rulers, and thus they do not seem fully reliable. However, there must be a grain of truth in their poems, since they recited them before these same rulers and their children who would have rejected the account if it had been entirely false - viewing it as a mockery rather than praise.

Consequently, what - in Snorri's eyes - would constitute such an invented story not to be trusted, and perceived as a mockery? It may be that the author of Heimskringla endeavoured to preclude the situation presented by the one who penned Morkinskinna - namely, the possibility that the defector or coward would be shown as a warrior

${ }^{29}$ Nordal, Snorri Sturluson, 166; Kari E. Gade, 'Morkinskinna's Giffarðspattr: Literary Fiction or Historical Fact?', Gripla, xi (2000), 183 ff.; cf. Ghosh, Kings' Sagas, $51 \mathrm{f}$. (for further reading, see the latter two studies).

${ }^{30}$ Ghosh, Kings' Sagas, 51 ff. 
who heroically fought in some battle. He believed, in this narrow scope, that the control exercised over the skalds by the ruler's circle sufficiently ensured that nothing like this would occur. To refer to the most straightforward method whereby a record can be deemed credible if it honestly takes account of the defeats of the circle or milieu it was originally written in: there is the other side of the coin, though; what if the ruler was actually disreputably defeated? It can be guessed that such a defeat would have been elevated to the rank of a 'moral victory'. ${ }^{31}$ Apparently, fundamental to Snorri's historical epistemology were categories related to the notion of honour: whether a statement made about somebody was true could be decided based on whether it did not vilify its object. Rather than control from the eyewitnesses, be it imperfect ones, Snorri points to a community for which the repute of the ruler prevailed over the truth. To paraphrase La Rochefoucauld's aphorism used as a motto hereto, Snorri assumed that none of the skalds would have ever dared to praise the monarch for inexistent virtues, for such an insult would not have passed unpunished. For a change, he slurred over the fact that the poets unconscionably embellished their heroes' accomplishments, in case the latter had really occurred. In other words, it was the very fact that somebody took part in a battle that emphasis was placed on, rather than the presentation of this fact; to rephrase, ascertainment of the fact was focal, rather than the unavoidable bias. ${ }^{32}$ Snorri accepted the latter

${ }^{31}$ Information on the ruler's death at the beginning of a battle may be an important message, suggesting that he had deserved the defeat [see Paweł Żmudzki, Wtadca $i$ wojownicy. Narracje o wodzach, drużynie $i$ wojnach w najdawniejszej historiografii Polski i Rusi (Wrocław, 2009), $64 \mathrm{ff}$.], or may contribute to his glory as a martyr [the Norwegian chronicler gives such information on St Olaf: Theodoricus, De antiquitate regum Norwagiensium. On the Old Norwegian Kings, ed. by Egil Kraggerud (Oslo, 2018), chap. 15, 76].

${ }^{32}$ Cf. Bagge, review of Ghosh, 99: "Snorri here [i.e. in the passage of the Heimskringla prologue under discussion] states two principles that are essential to all historical research: the distinction between factual statements and bias [emphasis mine - R.R.], and the possibility to control the information". As to the first point, I should remark that differentiation between the two is not always possible, and is certainly uneasy. In some cases, the selection of 'facts' by the author of the record, and not just the very way in which they are presented, prevails in the evaluation of the character or event. What about a situation where two different sources share an attitude toward an individual whilst quoting contradictory 'facts' regarding him? Or, when two parties to the conflict ascribe to 
with the 'benefit of inventory' and this is why he considered it "as true everything [emphasis mine - R.R.] that is found in those poems about their expeditions and battles". ${ }^{33}$

Was Snorri right at all, then? The aforenoted statement alone triggers doubts as it suggests that records ought to be absolutely trusted, not only as to the 'facts' presented or referred to. He moreover affirmed, on the one hand, that the audiences expected from the poets to hyperbolise the real events, whilst assuming, on the other, that the public would not tolerate a too far-fetched hyperbolisation. But, what is the limit of such exaggeration? Can one really reduce the matter in question to a situation where an ordinary coward would have been praised? The example taken from Morkinskinna shows, nevertheless, that there is a fundamental contradiction within Snorri's reasoning, and that it is a sort of wishful thinking. True, the purport of Eldjarn's poem was opprobrious, but as such, it was perceptible only to those who were aware of the actual course of events - namely, to the skald and the story's character. For the other listeners, the ironic and scabrous message was unreachable, and thus no control of the piece's credibility by the audience was possible; this is attested by the response of the lawyer who had listened to it. Eldjarn could revile Giffard with impunity, eulogising his fictitious traits. A rhetorical question arises, is Snorri not overestimating the ruler and his circle - the ones he otherwise refers to? Would they have not been satisfied, essentially, by a poem that would praise the alleged heroism of a certain Norman knight? And, would they have not accepted the adopted literary convention, even if they knew how things were in reality? In any case, as Snorri put it, "it is indeed the habit of poets to praise most highly the one in whose presence they are at the time".

themselves the victory in a battle? What is a fact, and what is the bias in cases like these?

${ }^{33}$ The question whether, in Snorri's opinion, the skalds could be trusted also in other matters, unrelated to a war, seems to be a hair-splitting (cf. Ghosh, Kings' Sagas, 52 f.; Bagge, review of Ghosh, 99). After all, military issues were the real standard of medieval historiography; Gallus Anonymous expressed it straight away by stating that his actual focus is the war, and not the Gospel; Gesta principum Polonorum. The Deeds of the Princes of the Poles, transl. Paul W. Knoll and Frank Schaer, preface by Thomas Bisson (Budapest-New York, 2003), 212. Much in the same way, Snorri points to the major area of his interest. 
So, why could the skaldic poetry, despite its idealising character, be used as a source regarding the history of Scandinavian rulers? The answer is, should their praises have been too far-fetched, heroising cowardice and desertion, it would have been interpreted as mockery. This being the case, it could be taken at face value that the heroic deeds had been part of the reality, even if they were not as magnificent as depicted by the court poets. The sagamadr's assumption has more in common with rhetoric than modern criticism and source analysis. The scholars who (probably, unconsciously) refer to this assumption do not contribute to cognition of the past reality. The proper method is, instead, to accept the source as it is, and to put forth its ideological aspect, as well as the way in which the represented world has been brought to life, as the research problem.

transl. Tristan Korecki

\section{SELECTED BIBLIOGRAPHY}

Andersson Theodore M., 'The Oral Sources of Óláfs Saga helga in Heimskringla', Saga-Book, xxxii (2008), 5-38.

Bagge Sverre, review of: Shami Ghosh, Kings' Sagas and Norwegian History. Problems and Perspectives (Leiden-Boston, 2011), Journal of English and Germanic Philology, cxii, 1 (2013), 98-100.

Boulhosa Patricia P., Icelanders and the Kings of Norway. Medieval Sagas and Legal Texts (Leiden-Boston, 2005).

Buc Philippe, 'Noch einmal 918-919. On the Ritualized Demise of Kings and of Political Rituals in General', in Gerd Althoff (ed.), Zeichen, Rituale, Werte: Internationales Kolloquium des Sonderforschungsvereichs 496 an der Westfälischen Wilhelms-Universität Münster (Münster, 2004), 151-78.

Cetwiński Marek, Historia i polityka. Teoria i praktyka mediewistyki na przykładzie badań dziejów Ślaska (Kraków, 2008).

Gade Kari E., 'Morkinskinna’s Giffarðspattr: Literary Fiction or Historical Fact?', Gripla, xi (2000), 181-97.

Ghosh Shami, Kings' Sagas and Norwegian History. Problems and Perspectives (LeidenBoston, 2011).

Meulengracht Sørensen Preben, 'The Prosimetrum Form. 1: Verses as the Voice of the Past', in Russell Poole (ed.), Skaldsagas: Text, Vocation, and Desire in the Icelandic Sagas of Poets (Berlin-New York, 2000), 172-90.

Michałowski Roman, Princeps fundator. Studium z dziejów kultury politycznej w Polsce X-XIII wieku (Warszawa, 1993²).

Morawiec Jakub, Między poezją a polityką. Rozgrywki polityczne w Skandynawii XI wieku w świetle poezji ówczesnych skaldów (Katowice, 2016). 
Morkinskinna, ed. by Finnur Jónsson (København, 1932).

Phelpstead Carl, Holy Vikings: Saints' Lives in the Old Icelandic Kings' Sagas (Tempe, 2007).

Rutkowski Rafał, Pótnocna tradycja historyczna wprowadzona $w$ nurt dziejów powszechnych. Kronika Mnicha Teodoryka "O starożytności norweskich królów" (koniec XII wieku) (Toruń, 2019).

Snorri Sturluson, Heimskringla. Nóregs Konunga Sögur, ed. by Finnur Jónsson, i (København, 1893-1900).

Żmudzki Paweł, Wtadca $i$ wojownicy. Narracje o wodzach, drużynie $i$ wojnach $w$ najdawniejszej historiografii Polski i Rusi (Wrocław, 2009).

Rafał Rutkowski - history of medieval historiography, history of medieval Scandinavia; postdoctoral researcher at the Institute of Archaeology and Ethnology, Polish Academy of Sciences; e-mail: rr.rutkowski@wp.pl 